\title{
Purification of the body and the reign of God in the Gospel of Mark
}

\author{
Elizabeth E. Shively
}

\begin{tabular}{|c|c|}
\hline Date of deposit & 17022020 \\
\hline Document version & Author's accepted manuscript \\
\hline Access rights & $\begin{array}{l}\text { Copyright (c) } 2020 \text { The Author(s). Published by Oxford University } \\
\text { Press. All rights reserved. This work has been made available } \\
\text { online in accordance with publisher policies or with permission. } \\
\text { Permission for further reuse of this content should be sought from } \\
\text { the publisher or the rights holder. This is the author created } \\
\text { accepted manuscript following peer review and may differ slightly } \\
\text { from the final published version. }\end{array}$ \\
\hline $\begin{array}{l}\text { Citation for } \\
\text { published version }\end{array}$ & $\begin{array}{l}\text { Shively, EE 2020, 'The purification of the body and the reign of } \\
\text { God in the Gospel of Mark', Journal of Theological Studies, vol. } \\
\text { Advance article, flz171. https://doi.org/10.1093/jts/flz171. }\end{array}$ \\
\hline $\begin{array}{l}\text { Link to published } \\
\text { version }\end{array}$ & https://doi.org/10.1093/jts/flz171 \\
\hline
\end{tabular}

Full metadata for this item is available in St Andrews Research

Repository at: https://research-repository.st-andrews.ac.uk/

\begin{tabular}{l|l|l|} 
University of & FOUNDED \\
St Andrews & $1413 \mid$
\end{tabular}




\title{
PURIFICATION OF THE BODY AND THE REIGN OF GOD IN THE GOSPEL OF MARK*
}

\begin{abstract}
The thesis of this study is that the Markan Jesus's activities of healing and exorcisms are evocative of resurrection of the body. Through the accumulation of these stories Mark communicates that Jesus has come to address the problem of human mortality in light of the nearness of God's reign. These activities anticipate Jesus's resurrection from the dead, which pioneers the purification of the body at the turn of the ages. I show that Mark's presentation of Jesus' healings and exorcisms crucially reflect ideas of (im)purity in Jewish scripture and tradition that are bound up with mortality. In light of this background, I show that Mark presents Jesus' healings and exorcisms as anticipations of Jesus's bodily resurrection. These resurrection-type stories depict the movement from the mortality incurred by defiling diseases or defiling spirits to the immortality of God's reign. The repetition of resurrectiontype healings that eventually culminate in Jesus' own resurrection suggests that the announcement of God's reign is not only about responding to the call for repentance from sin (1:14-15), but also about having one's body raised. Thus, Mark presents not only a theology of the cross, but also a theology of the resurrection as the purification of God's people.
\end{abstract}

- This article grew from a paper I presented for the 2016 Mark seminar of the Society of Biblical Literature annual meeting. I am grateful for the constructive feedback of the seminar members, which sharpened my thinking and my argument. 


\section{INTRODUCTION}

DuNN expresses a view that has become axiomatic in the investigation of purity in the Gospels when he states, 'The purity text in the Gospel tradition is, of course, Mark 7.1-23.'1 This conflict story between Jesus and the scribes and Pharisees over hand-washing has been the touchstone for deciding Jesus' view of purity. While recent scholarship has concluded that Jesus does not reject purity wholesale, it favors the view that he - or his portrayal by the evangelists - is indifferent towards ritual purity according to the Levitical law codes and their interpretation in Jewish tradition because he prioritizes an internal purity of the heart expressed in obedience to the commands of Torah. ${ }^{2}$ By contrast, I argue that Mark conveys an idea of purity that elevates not only what is internal but also what is external; not only the heart, but also the body. Specifically, Mark portrays Jesus's activities of healing people from disease and disability and his exorcisms of impure spirits as evocative of resurrection from the dead. ${ }^{3}$ Thus, Jesus' activities address the problem of human mortality in light of the nearness of God's reign, which signals the unmitigated presence of God with his people; and anticipate Jesus's resurrection from the dead, which pioneers the purification of the body at the turn of the ages.

${ }^{1}$ James D. G. Dunn, 'Jesus and Purity: An Ongoing Debate', NTS 48 (2002), p. 461.

${ }^{2}$ I discuss this scholarship below.

${ }^{3}$ By calling the healings and exorcisms "evocative of resurrection" I do not mean that these are transposed resurrection accounts, such as a number of scholars have argued about the Transfiguration (see, for example, Robert H. Stein, 'Is the Transfiguration (Mark 9:2-8) a Misplaced Resurrection-Account?' JBL 95 [1976], pp. 79-96). Rather, I mean that Mark's descriptions of healings and exorcisms are powerfully suggestive of bodily resurrection from the dead. 


\section{INTERPRETATIVE ISSUES}

Jerome Neyrey’s oft-cited article, 'The Idea of Purity in Mark’s Gospel, ${ }^{4}$ investigates the role of purity in Mark based on the evangelist's depiction of Jesus, the Jewish authorities, and others in the Gospel. Neyrey's analysis is informed by the early work of anthropologist Mary Douglas, ${ }^{5}$ in which purity is a symbolic system that functions to create order and maintain social boundaries. The same approach to purity has subsequently appeared in the scholarship of Bruce Malina, David Rhoads, and Marcus J. Borg, and has significantly influenced Gospels and historical Jesus studies $;^{6}$ however, I focus my discussion on Neyrey's work in order to sharpen the specific concerns of my argument.

${ }^{4}$ Jerome H. Neyrey, 'The Idea of Purity in Mark's Gospel', Semeia 35, ed. John H. Elliot (Decatur, GA: Scholars Press, 1986), pp. 91-128. See also idem, 'Clean/Unclean, Pure/Polluted, and Holy/Profane-The Idea and System of Purity', in The Social Sciences and New Testament Interpretation, ed. Richard Rohrbaugh (Peabody, MA: Hendrickson, 1996), pp. 80-106.

${ }^{5}$ Mary Douglas, Purity and Danger: An Analysis of Concepts of Pollution and Taboo (London/New York: Routledge, 1966, 2002 [with new preface]).

${ }^{6}$ David Rhoads, 'Social Criticism: Crossing Boundaries,' in Mark \& Method: New Approaches in Biblical Studies, ed. Janice Capel Anderson and Stephen D. Moore (Minneapolis: Fortress, 1992), pp. 135-61; idem, Reading Mark, Engaging the Gospel (Minneapolis: Fortress, 2004), pp. 140-75; Marcus J. Borg, Jesus in Contemporary Scholarship (Valley Forge, PA: Trinity Press International, 1994); Bruce J. Malina, 'Clean and Unclean: Understanding Rules of Purity,' in The New Testament World: Insights from Cultural Anthropology, $3^{\text {rd }}$ ed. (Louisville, KY: Westminster John Knox, 2001), pp. 161-97. For additional critique of this scholarship, see Jonathan Klawans, Impurity and Sin in Ancient Judaism (Oxford: Oxford University Press, 2000), pp. 12, 137, 144-45. 
Following Douglas, Neyrey defines purity as 'a map of a social system which coordinates and classifies things according to their appropriate place. ${ }^{7}$ Impurity, by contrast, is 'matter out of place. ${ }^{8}$ Based largely on evidence from rabbinic literature, Neyrey interprets the Jewish purity system according to a series of such 'maps' that coordinate and classify things, people, places, activities, and times according to a hierarchy of holiness, or purity ratings. ${ }^{9}$ Since the purity system and its observances functioned to delineate what or who was impure or pure, Neyrey argues that Jews of Jesus's day had to be aware constantly of these sorts of purity ratings in order to maintain the boundary lines that kept social structures in place. ${ }^{10}$ According to Neyrey, Mark's Jesus constantly violates the various purity 'maps'. ${ }^{11}$

${ }^{7}$ Neyrey, 'Idea of Purity', p. 94 . He comments that, 'purity is best understood in terms of its binary opposite, 'dirt.' See also Jacob Neusner, 'Map Without Territory: Mishnah's System of Sacrifices and Sanctuary', HR 19 (1979), pp. 103-127; Malina, New Testament World, pp. 165-70.

${ }^{8}$ This is extrapolated from Douglas's definition of 'dirt as matter out of place.' Douglas explains that 'It implies two conditions: a set of ordered relations and a contravention of that order. Dirt, then, is never a unique, isolated event. Where there is dirt there is a system. Dirt is the by-product of a systematic ordering and classification of matter, in so far as ordering involves rejecting inappropriate elements. The idea of dirt takes us straight into the field of symbolism and promises a link-up with more obviously symbolic systems of purity.' Douglas, Purity and Danger, p. 36.

${ }^{9}$ In social scientific research, a 'map' is a structure of ideas or concepts or, in this case, entities (like people, places, things, activities, and times) that shows how they are interrelated.

${ }^{10}$ Neyrey, 'Idea of Purity', p. 102.

${ }^{11}$ Neyrey, 'Idea of Purity', p. 108. 
As a result, Jesus receives two competing purity ratings. On the one hand, Mark (the narrator) and God give Jesus the highest purity rating, while those Jews whom society has given the highest purity ratings (e.g., Pharisees, scribes) give Jesus a low purity rating by attributing his work to the power of Satan and an impure spirit (Mark 3:22-30). ${ }^{12}$ Mark's Jesus rejects the conventional idea of purity because it has to do with external matters that are intended to maintain social boundaries. Instead, Jesus cares about the internal purity of the heart, expressed in obedience to the Ten Commandments (e.g., Mark 7:1-23, esp. v. 15). ${ }^{13}$

But a problem persists with Neyrey's definition of purity. By restricting it to a system of social order and boundaries, he fails to acknowledge the extent to which Israel's purity system, including the idea of pollution, has its origin in and receives its value from God's covenant with his people. ${ }^{14}$ In other words, although Israel's purity system is indeed symbolic, it is also fundamentally, deeply theological. Moreover, Neyrey's conclusions are problematic because he neglects the biblical foundation of the rabbinic rules and the thought

\footnotetext{
${ }^{12}$ Neyrey, 'Idea of Purity', p. 109.

${ }^{13}$ Neyrey, 'Idea of Purity', p. 113.

${ }^{14}$ In fact, Mary Douglas reversed her position on the social function of purity systems
} in subsequent writings. She comments, 'the more that pollution theory developed, and the more that pollution was seen as the vehicle of accusations and downgradings, the more I was bound to acknowledge that it does not apply to the most famous instance of the Western tradition, the Pentateuch.' Douglas, Leviticus as Literature (Oxford: Oxford University Press, 1999), p. viii. See also, idem, 'Deciphering a Meal,' Daedalus, (1972), pp. 61-81; idem, 'Self Evidence, Henry Myers Lecture' Proceedings of the Royal Anthropological Institute (1972), pp. 27-44; idem, In the Wilderness: The Doctrine of Defilement in the Book of Numbers (Sheffield: Sheffield University Press, 1993). 
of Jesus, the evangelists and their audience. ${ }^{15}$ The purpose of the ritual purity system was not, in fact, to delineate a hierarchy of that which or who was impure/pure, as Neyrey maintains, but to provide all of Israel — from poor to priest — with a way of rectifying states of impurity. ${ }^{16}$ Neyrey's failure adequately to investigate the biblical foundation of Israel's ritual purity system leads to flawed conclusions about the significance of Jesus's death and resurrection. ${ }^{17}$ Neyrey argues - correctly, in my view - both that 'death is the ultimate sign of the power of sin and Satan' and that 'it means irrevocable uncleanness. ${ }^{18}$ Indeed, according to the Torah, corpse impurity brings the greatest ritual defilement (Num 5, 19). Nevertheless, he concludes that death does not render Jesus unclean because of its stimulus: ${ }^{19}$

Jesus' death is not polluting for it comes from obedience to God, not from the power of sin. By raising Jesus from the dead, God vindicates him, testifying that he is indeed

${ }^{15}$ Neyrey relies on the work Jacob Neusner, whom Hyam Maccoby criticizes for the same methodological problem in Maccoby, Ritual and Morality: The Ritual Purity System and its Place in Judaism (Cambridge: Cambridge University Press, 1999), pp. 59-60, 96-100. Neusner's approach to uncleanness as part of a hierarchical classification of social beings is evident, for example, in Jacob Neusner and Bruce D. Chilton, 'Uncleanness: A Moral or an Ontological Category in the Early Centuries A.D.?', BBR 1 (1991), pp. 63-80. Neusner wrote the first half of this article.

${ }^{16}$ I discuss textual evidence in detail, below.

${ }^{17}$ Even though Neusner may be criticized for similar methodological problems, some of his work gestures towards the idea that the law addresses human moral character rather than boundaries. See, for instance, 'First Cleanse the Inside', NTS (1979), pp. 486-496, esp. 494.

\footnotetext{
${ }^{18}$ Neyrey, 'Idea of Purity', p. 114.

${ }^{19}$ Neyrey, 'Idea of Purity', p. 114. His emphasis.
} 
'Son of God' (see 15:39) and proving that he fully deserved his high purity rating. Jesus then enters the very circle of God's presence and sits on God's throne, a thing unthinkable for a corpse. $^{20}$

Quite the contrary, the Torah does not make any such qualifications; a corpse is still a corpse, and every corpse is defiling. Thus, the corpse of Jesus, like every other corpse, would have been an impurity bearer of the greatest kind. Neyrey therefore also correctly states that it is 'unthinkable for a corpse' to enter 'the very circle of God's presence'. But while his singular view of Jesus's death leads him to the conclusion that Jesus' resurrection was a sign or proof that this particular death was not polluting, I wish to demonstrate just the opposite, that Jesus's resurrection was necessary for him to enter God's presence precisely because every corpse - including his - is ritually defiling. In other words, by raising Jesus from the dead, God not only vindicated Jesus, but also purified him.

I turn now to highlight the work of those who have investigated purity in Mark by seeking to discern the historical Jesus's attitude towards purity through an analysis of the conflict settings in chapters 2-3 (Sabbath and table fellowship) and in chapter 7 (food laws). ${ }^{21}$

${ }^{20}$ Neyrey, 'Idea of Purity', p. 114.

${ }^{21}$ See, for example, Jacob Neusner, The Idea of Purity in Ancient Judaism (SJLA 1; Leiden: Brill, 1973); idem, From Politics to Piety: The Emergence of Pharisaic Judaism (Englewood Cliffs, NJ: Prentice-Hall, 1973); E. P. Sanders, Jesus and Judaism (London: SCM, 1985); idem, Jewish Law from Jesus to the Mishnah: Five Studies (London: SCM, 1990); idem, Judaism: Practice and Believe, 63 BCE-66 CE (London: SCM, 1992); James D. G. Dunn, Jesus, Paul and the Law (London: SPCK, 1990); idem, The Parting of the Ways between Christianity and Judaism (London: SCM, 1991); Hans Hübner, Das Gesetz in der synoptischen Tradition: Studien zur These einer progressive Qumranisierung und Judaisierung innerhalb der synoptischen Tradition, 2d ed. (Göttingen: Vandenhoeck \& 
Older Protestant scholarship believed that the historical Jesus rejected the Levitical purity system. ${ }^{22}$ Recent scholarship, however, takes a more nuanced approach as it aims to place Jesus the Jew in the "complex and diverse" ${ }^{23}$ setting of Second Temple Judaism. Dunn is representative of the field in his examination of the controversies over table fellowship and Sabbath law in Mark 2:1-3:6, and food laws in Mark 7:1-23. He surmises that the driving issues in these passages are about what practices create boundary lines between the people of God and others. ${ }^{24}$ In his interpretation of Mark 7:1-23 he concludes that Jesus did not Rupprecht, 1986; Bruce Chilton, The Temple of Jesus: His Sacrificial Program within a Cultural History of Sacrifice (University Park, PA: Pennsylvania State University, 1992); idem, Rabbi Jesus: An Intimate Biography (New York: Doubleday, 2000); Franz Georg Untergassmair, 'Jesus und die jüdische Gesetzestradition im Lichte urchristlicher Interpretation (Mk 7,1-13),' Forschungen zum Neuen Testament und seiner Umwelt: Albert Fuchs Festschrift; Linzer Philosophisch-Theologische Beiträge 7. Ed. Christoph Niemand (Frankfurt: Lang, 2002), pp. 175-90.

${ }^{22}$ For a list of studies arguing that Jesus opposes the Levitical purity system, see E. P. Sanders, Jesus and Judaism (London: SCM, 1985), 396-97, notes 6-7. In addition, those who make this argument include John D. Crossan, The Historical Jesus: A Life of a Mediterranean Jewish Peasant (New York: HarperCollins, 1991), 322-23, 355; Marcus J. Borg, Conflict, Holiness and the Politics in the Teaching of Jesus (Studies in the Bible and Early Christianity 5; New York: Edwin Mellen, 1984), 136; and Scot McKnight, 'Jesus and James on Israel and Purity', in James the Just and Christian Origins (ed. Bruce Chilton and Craig A. Evans; SNT 98; Leiden: Brill, 1999), pp. 91-98.

${ }^{23}$ Dunn, 'Jesus and Purity: An Ongoing Debate', NTS 48 (2002), p. 449.

${ }^{24}$ Dunn, Jesus, Paul and the Law, 28. In his interpretation of Mark, Dunn argues that social context drives the forms of the sayings in Mark 7:15 and its parallel in Matthew: 
abandon ritual purity altogether, but was indifferent to purity laws in order to show that he was most concerned with purity of heart. ${ }^{25}$ Like Neyrey, Dunn focuses on social boundary lines and internal purity, but from a different methodological perspective.

Bucking the scholarly trend of examining controversy texts, Thomas Kazen looks at non-controversy traditions in the Synoptic Gospels that have to do with skin disease, bodily discharges, and the corpse against the background of ritual purity laws in the Torah and their developing tradition in Judaism. ${ }^{26}$ Nevertheless, his goal remains the same as Dunn's: to sift through traces of purity issues in the tradition in order to discern the historical Jesus's attitude towards purity. He believes that such traces are present, but hidden by the christological interests of the evangelists. Like Dunn (and Neyrey), Kazen argues that the historical Jesus

Matthew's more primitive, less radical version addresses a congregation for whom food laws are not a contentious issue, Mark's interpretive, radical version addresses a congregation for whom food laws have created boundary-lines within the people of God. Dunn, Jesus, Paul and the Law, pp. 50-53.

${ }^{25}$ Dunn, 'Jesus and Purity', p. 461. For similar views that Jesus does not reject ritual purity, but priorities moral purity see Roger P. Booth, Jesus and the Laws of Purity: Tradition, History and Legal History in Mark 7 (JSNTSup 13; Sheffield: JSOT, 1986), pp. 46-50; Eyal Regev, 'Pure Individualism: The Idea of Non-Priestly Purity in Ancient Judaism', JSJ 31 (2000), p. 200 n. 75; idem, 'Moral Impurity and the Temple in Early Christianity in Light of Ancient Greek Practice and Qumranic Ideology', HTR 97 (2004), pp. $387-88$.

${ }^{26}$ Thomas Kazen, Jesus and Purity Halakhah: Was Jesus Indifferent to Impurity? (ConBNT 38; Stockholm: Almqvist \& Wiksell, 2002); See also idem, Scripture, Interpretation, or Authority?: Motives and Arguments in Jesus' Halakic Conflicts WUNT 320 (Tübingen: Mohr Siebeck, 2013). 
was indifferent to ritual purity; but unlike Dunn, he argues that Jesus was indifferent because he believed himself to be the authoritative agent of God's kingdom. That is, the Gospel accounts do not record Jesus performing any purity rituals after touching, for example, a leper or corpse, not on the basis of his own holiness, but on the basis of the power of God's reign. $^{27}$

Like Kazen, I wish to examine the role of ritual purity in the Gospel of Mark by looking at the accounts of Jesus' healings and exorcisms against the background of the ritual purity laws in the Torah and their development in Second Temple Judaism. But mine is not a historical Jesus study; rather, I am interested in analysing the final form of the Gospel to discern what Mark communicates about Jesus and purity. In view of the preceding survey, I seek to demonstrate that not only purity of the heart, but also purity of the body is central to Mark's Christology, the nature of the reign of God, and the activity of Mark's Jesus.

\section{JESUs’s EXorcisms AND HEALINGS IN JEWISH CONTEXT}

Beginning with 1:14-15, Mark portrays Jesus as the agent of God's reign and the mediator of its accompanying eschatological benefits, particularly exorcisms and healings. Between 1:14-

${ }^{27}$ This line of argument is contrary to that of Neyrey’s. Nerey argues that Mark does not record Jesus performing any purity rituals because he is never defiled by touching impurity bearers. Others who conclude that Jesus was indifferent to purity include, for example, Hanna K. Harrington who comments, ‘Although apparently an observant Jew, Jesus appears to marginalize the whole issue of ritual purity by teaching that only what comes from a person's heart will defile him (Mt. 23.25; Mk 7.14-23; Lk 11.38-40).' Harrington, The Purity Texts (T\&T Clark London; New York: Continuum, 2004), p. 42. 
10:52, that is, between Jesus' announcement of the nearness of God's reign and his entry into Jerusalem directly preceding the passion narrative, Mark narrates nine healings, four exorcisms, and three summary reports of Jesus' activities that include healings and exorcisms $(1: 32-34,39 ; 3: 7-12 ; 6: 53-56)$.

Informed by Umberto Eco, I assume that the evangelist and his audience belong to an interpretative community with a cultural encyclopedia informed by a shared historical, social, and political context - crucially including the Jewish scripture and tradition - that provides access to common knowledge so that they may engage in competent communication. ${ }^{28}$ Also informed by Eco, I assume that the evangelist relies on the informed audience to take an active role to fill in gaps in the text, that is, to make connections between what is in the text (i.e., Mark's description of Jesus's healings and exorcisms) and what the text infers. ${ }^{29}$ In light of these assumptions, I look at Jewish scripture and tradition to illuminate Mark's presentation of Jesus's healings and exorcisms and draw out those inferences.

I wish to establish that rectification of impurity is a crucial lens that informs an understanding of Jesus's healings and exorcisms in Mark. I show that Jesus's healings and

\section{${ }^{28}$ Umberto Eco, Semiotics and the Philosophy of Language (London: Macmillan} Press, 1984), pp. 46-86. Eco states that, 'The encyclopedia is the regulative hypothesis that allows both speakers to figure out the 'local' dictionary they need in order to ensure the good standing of their communicative interaction,' p. 80.

${ }^{29}$ According to Eco, 'The text interpretation is possible because even linguistic signs are not ruled by sheer equivalence (synonymy and definition); they are not based upon the identity but are governed by an inferential schema; they are, therefore, infinitely interpretable.' Eco, 'The Theory of Signs and the Role of the Reader,' The Bulletin of Midwest Language Association 14 (1981), p. 44. See also idem, Role of the Reader: Exploration in the Semiotics of Texts (Bloomington: Indiana University Press, 1979, 1981). 
exorcisms correspond to two phenomena whereby the Jewish scriptures make provision for the rectifying purification of the body: first, the provision of purity rituals to rectify the three major ritual impurities, and second, the eradication of natural disabilities at the time of God's eschatological reign. These two phenomena share a concern with the rectification of those physical defilements and/or disabilities that prevent human beings from dwelling in the presence of a holy God.

\section{Jesus's Healings/Exorcisms and the Rectification of Major Ritual Impurity}

The foci of three healings and two exorcisms correspond to the three sources of major ritual impurity for which the Torah provides rectifying purity rituals:

1) Corpse contagion (Num 5, 19) — Mark 5:1-20, exorcism of Gerasene demoniac; 22$24+35-43$, raising of Jairus's daughter; 9:14-29, exorcism of boy who looks 'like a corpse' and is assumed to be dead.

2) Scale disease (Lev 13-14) - Mark 1:40-45, healing of the leper.

3) Abnormal genital discharge (Lev 15) — Mark 5:24-34, healing of woman with issue of blood.

In the accounts of the leper, the woman with the flow of blood, and Jairus' daughter, the Markan Jesus heals people who experience the three major ritual contagions. Also, Jesus encounters the most potent ritual contagion of death in the account of the Gerasene demoniac, in that this figure lives among tombs. ${ }^{30}$ Likewise, Jesus encounters 'death' when the boy with

${ }^{30}$ According to the Torah, a person can become defiled by a corpse either through direct contact or by sharing an overhang (e.g. a room; Num 19). By extension, according to Second Temple halahkah and rabbinic writings, 'corpse impurity is believed to spurt upwards through a grave contaminating anyone who walks over it.' Harrington, Purity Texts, pp. 7273. Thus, Jews in the Second Temple period sought to prevent acquiring impurity by marking 
a deaf and dumb spirit whom he heals becomes 'like a corpse,' and he consequently takes

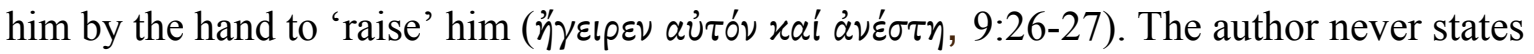
that Jesus becomes defiled, nor does he ever report that Jesus participates in purification rites. ${ }^{31}$ It may be that Mark does not feel the need to communicate such details to an informed audience with whom he shares a cultural encyclopedia. Nevertheless, Mark's selection and arrangement has the effect of suggesting that Jesus embodies purity and exhibits the "principle... of reverse contagion, according to which the pure might purify the impure" (see Hagg 2:15-19). ${ }^{32}$

The Torah describes the three major impurities within a larger purity system that is grounded in the holiness or 'set-apartness' of Israel's God. ${ }^{33}$ God is holy because he is uniquely great and uniquely good. ${ }^{34}$ Hence, for God to dwell with Israel, Israel must be holy, or set apart. Thus, for example, God's holiness is the ground for the prohibition against eating unclean creatures. To support the holiness established by such prohibitions, Lev 11:44 says, 'I am the Lord your God; sanctify yourselves therefore, and be holy, for I am holy' (cf.

graves so as not to be defiled by them (m. $M Q 1.2 ; \mathrm{b} M Q 5 \mathrm{~b}$; cf. the white-washed graves of Matt 23:27; Luke 11:44).

${ }^{31}$ I touch on this issue in my discussion of Kazen, above.

${ }^{32}$ A Comparative Handbook to the Gospel of Mark: Comparisons with Pseudepigrapha, the Qumran Scrolls, and Rabbinic Literature (ed. Bruce Chilton, Darrell Bock, Daniel M. Gurtner, Jacob Neusner, Lawrence H. Schirffman, and Daniel Oden; NTGJC 1; Leiden: Brill, 2010), p. 202.

${ }^{33}$ Hannah Harrington, The Impurity Systems of the Rabbis and Qumran (Atlanta: Scholars Press, 1993), p. 28.

${ }^{34}$ For a discussion of God's holy character, see Jay Sklar, Leviticus: An Introduction and Commentary (TOTC; Downers Grove: IVP, 2014), pp. 39-40. 
20:22-26). God's holiness is also the ground for keeping the moral aspects of the law. In Lev 19:2-3 we consequently read, 'You shall be holy, for I the Lord your God am holy. You shall each revere your mother and father, and you shall keep my sabbaths: I am the Lord your God. Do not turn to idols or make cast images for yourselves: I am the Lord your God.' Indeed, God's holiness is the foundation for the entire purity system and its various rituals. Because both moral and physical impurities 'cause disruptions in the divine-human relations, ${ }^{, 35}$ God both provides and requires means of restoring the divine-human relations through atonement and purification rituals that address the whole person, both internally and externally.

As I mentioned above, the Pentateuch identifies three sources of major physical impurity: Corpse contamination (Num 5, 19; the most potent), scale disease (Lev 13-14), and abnormal genital discharge (Lev 12,15). Numbers 5:1-3 joins them, requiring those with all three impurities to be isolated from the camp — God's dwelling place in wartime — so as not to defile it. While scale disease, genital discharge, and corpse contamination are not essentially related, they take on meaning as a category through the corresponding rituals that God commands. ${ }^{36}$ They have common characteristics — like members of a family—sharing results, consequences, and requirements for purification. Moreover, they share features of the impurity and purification requirements for unintentional sins (see Lev 4). Like unintentional sins (offensive acts), major physical impurities (offensive states) defile God's dwelling place

\footnotetext{
${ }^{35}$ Frank Gorman, Divine Presence and Community: A Commentary on the Book of
} Leviticus ITC (Grand Rapids: Eerdmans, 1997), 16. See further Harrington, Impurity Systems of the Rabbis and Qumran, pp. 28-35.

${ }^{36}$ Roy Gane has observed that the elements of a ritual do not have meaning in and of themselves, but that they obtain meaning when they are authorized, in this case, by Israel's God. Gane, Cult and Character: Purification Offerings, Day of Atonement, and Theodicy (Winona Lake, IN: Eisenbrauns, 2014). 
and carry a consequence of death if left unaddressed. Thus, both require the or purification offering, for atonement. These essentially unrelated physical states are inimical to life with a holy God and require rectifying purification.

Unlike unintentional sin, however, to become ritually impure is not sinful and is at times unavoidable. ${ }^{37}$ The laws about ritual purity address conditions that, unlike sin, do not always come about by choice or in some cases come about through acts that are natural and good, like burying the dead, sexual intercourse, and giving birth. Yet the fact that these sources of ritual impurity are joined to one another and to unintentional sin in their offensiveness to God and their requirement of the תאטח sacrifice suggests that we take a closer look for a common factor in order to explain their interrelationship.

Milgrom has argued that 'death' is the tie that binds the three sources of major impurity: each suggests a process of decay or the inevitability of death, which Israel's lifegiving God opposes. ${ }^{38}$ Maccoby has criticized this view as too narrow to account for all sources of impurity such as, for example, menstruation and seminal discharge, which seem to generate rather than take life. ${ }^{39}$ He suggests instead that Israel's ritual purity system knits

${ }^{37}$ Jonathan Klawans, 'Idolatry, Incest, and Impurity: Moral Defilement in Ancient Judaism,' JStJud 29 (1998), pp. 392-93.

${ }^{38}$ Milgrom, Leviticus 1-16: A New Translation with Introduction and Commentary (Anchor Bible, vol. 3; New York: Doubleday, 1992), pp. 766-68, 1001-1003; idem, 'Rationale for Cultic Law: The Case of Impurity,' Semeia 45 (1989): pp. 103-109. See also Harrington, Impurity Systems, 29; Baruch J. Schwartz, 'The Bearing of Sin in the Priestly Literature,' in Pomegranates and Golden Bells: Studies in Biblical, Jewish, and Near Eastern Ritual Law, and Literature in Honor of Jacob Milgrom, ed. David P. Wright, David N. Freedman, and Avi Hurvitz, (Winona Lake, IN: Eisenbrauns, 1995), p. 5.

${ }^{39}$ Maccoby, Ritual and Morality, p. 1. 
together both life and death. ${ }^{40}$ Other scholars have followed Maccoby's stress on the entire life-death cycle to suggest that mortality rather than death is better language for the common factor among the sources of ritual impurity. ${ }^{41}$ Accordingly, Cook suggests that the system of ritual purity 'centers around sexual differentiation, involuntary seminal emissions, disease, and death because it is these issues of corporeality that, in the Bible, symbolize the difference between human beings and God. ${ }^{42}$ Thus, Israel acknowledges that difference by means of the purity system, 'keeping mortality and its impurity away from the sacred realm, ${ }^{, 43}$ and thereby maintaining the well-being of the community.

${ }^{40}$ Maccoby, Ritual and Mortality, p. ix.

${ }^{41}$ Klawans comments that ancient Israelites 'separated themselves from what made them least God-like.' Klawans, Purity, Sacrifice, and the Temple: Symbolism and Supersessionism in the Study of Ancient Judaism (Oxford: Oxford University Press, 2006), p. p. 58. See also Tikva Frymer-Kensky, 'Pollution, Purification, and Purgation in Biblical Israel,' in The Word of the Lord Shall Go Forth: Essays in Honor of David Noel Freedman in Celebration of His Sixtieth Birthday, eds. C. L. Meyers and M. O'Connor (Winona Lake, IN: Eisenbrauns), pp. 399-414; Howard Eilberg-Schwartz, People of the Body: Jews and Judaism from an Embodied Perspective (Albany, NY: State University of New York Press, 1992), p. 31; David P. Wright, 'Unclean and Clean (OT)', in Anchor Bible Dictionary, VI (New York: Doubleday, 1992), pp. 729-41; Harrington, Purity Texts, pp. 34-36; Maccoby, Ritual and Morality, p. 1.

${ }^{42}$ Leslie A. Cook, 'Body Language: Women's Rituals of Purification in the Bible and Mishnah', in Women and Water: Menstruation in Jewish Life and Law, ed. Rahel Wasserfall (Waltham, MA: Brandeis University Press, 1999), p. 108.

${ }^{43}$ Harrington, Purity Texts, p. 108. 
Nevertheless, Qumran texts develop a specific association between impurity and death by equating corpse impurity with other impurities. For example, the instructions in 4Q274 1 i:4-9 forbid a woman with an abnormal genital discharge who is undergoing purification to touch either a pure or impure person or to mingle with others lest she contaminate the camp. Anyone who touches her is contaminated 'just as if he had been defiled by a human corpse' (v. 9; see also 4Q278). The writer of 4Q277 requires the red cow ritual, which the Torah mandates for purification from corpse impurity for 'a man purified from any impurity' (4Q277 1 ii 2) so that those who undergo the ritual are 'cle[an]sed of [human?] corpse defilement [and of every] other [defilement when the pri]est [spr]inkles the lustration water upon them...' (4Q277 1 ii 8-9). The implication is that all impurities are conjoined with death. $^{44}$

The connection of scale disease with death supports this implication. For example, in 4Q272, the impurity of scale disease is attributed to an evil spirit that '[comes and takes hold] [of the artery, making the blood recede up]wards and downwards' (4Q272 1 i 3) so that dead skin overtakes living skin. Healing comes when 'the spirit of life pulsates up and down and the flesh has grown' (4Q272 1 i 7; see also 4Q272 1 ii 1; 4Q266 6 1:6-13; 4Q269 7:1-8). The evil spirit obstructs the blood that bears the 'spirit of life,' rendering scale disease death-like. In this case, impurity, death, and evil spirits are joined. ${ }^{45}$ Qumran and other Second Temple

${ }^{44}$ See Joseph Baumgarten, Qumran Cave 4 XXV: Halakhic Texts: Discoveries in the Judaean Desert XXXV (Oxford: Clarendon Press, 1999), pp. 86-87.

${ }^{45}$ I follow Jonathan Klawans closely here, Impurity and Sin in Ancient Judaism, 88. See also Cecilia Wassen, 'What do the Angels Have Against the Blind and the Deaf? Rules of Exclusion in the Dead Sea Scrolls', in W. O. McCready and A. Reinharts, eds., Common Judaism: Explorations in Second Temple Judaism (Minneapolis: Fortress Press, 2008), p. 124. 
texts also attribute general disease and disability to evil spirits during the time of Belial/r's reign, which will come to an end at the end of the age. ${ }^{46}$ These sectarian texts suggest that some ancient Jews tied impurity specifically to death and the work of evil spirits.

Mark's presentation reflects this idea that mortality and, more specifically, death is the common factor that joins all impurity. Every healing and exorcism connected to major ritual impurity is tied crucially to death:

1) The healing of the leper (Mark 1:40-45). Scale disease was associated with death in the ancient world so that the one suffering from scale disease was viewed as a living corpse; for such a person to be healed was like being raised from the dead. ${ }^{47}$

2) The exorcism of the Gerasene demoniac (5:1-20). He lives in the tombs among the dead, cutting himself, with no one able to restrain him. The demons are intent on destroying him so that he is as good as dead until Jesus restores him to life.

3) The raising of Jairus' daughter (5:22-24, 35-43).

4) The healing of the woman with the issue of blood (Mark 5:24-34). Through intercalation and repetition, the healing of the 'daughter' with the 12-year flow of blood is framed narratively by the death and raising of Jairus's 12-year old daughter,

${ }^{46} 4 \mathrm{Q} 5601$ i 4; cf. Jub 10:1-10; TSol 11:2; 12:2; 13:3-4; 18:5-11, 13-14, 17-21, 23-37.

${ }^{47}$ The one with scale disease would have resembled a corpse with the white and withering skin (see Numbers 12:10-13). Josephus comments, 'But for the lepers, he suffered them not to come into the city at all; nor to live with any others; as if they were in effect dead persons. But if any one had obtained, by prayer to God, the recovery from that distemper, and had gained a healthful complexion again, such an one returned thanks to God, with several sorts of sacrifices: concerning which we will speak hereafter' (Ant. 3:11:3 §264). Rabbis considered the healing of a leper to be like the raising of the dead (LevRab 16 on Isa 57:19; bSanh. 47a). 
which signals a focus on the impurity of death as that to which the flow of blood points. $^{48}$

5) The exorcism of the deaf and mute boy (9:14-29). He looks like a 'corpse' and is assumed to be dead until Jesus 'raises' him.

The informed audience might infer that as the embodiment of purity, Jesus inaugurates the reign of God by rectifying, through his healings and exorcisms, that which causes the most potent disruption in the divine-human relations: death. Ultimately Mark will present the rectification of impurity through Jesus' embodiment of purity in his own resurrection from death in the account of the empty tomb. The plausibility of these inferences is strengthened by the second phenomena, which I discuss next.

2. Jesus's Healings/Exorcisms and the Eradication of Natural Disabilities with God's Reign

With three exceptions, ${ }^{49}$ Jesus's healings correspond to the eradication of natural disabilities at the time of God's eschatological reign, according to the prophet Isaiah: ${ }^{50}$

${ }^{48}$ Leviticus 15 indicates that someone with an defiling discharge who is undergoing purification would defile another person if he (or she) were to touch that person with unwashed hands or if that person were to touch him (or her). Nothing in Mark's text addresses these details, suggesting that Mark is not concerned with the question of whether or not the woman defiles Jesus. Rather, like those with skin disease, the woman is in a liminal place between life and death: because blood epitomizes a force of life, its loss epitomizes death (Lev 17:10-14; Deut 12:23).

${ }^{49}$ Healing from fever (1:29-30), leprosy/scale disease (1:40-45), and abnormal genital bleeding (5:25-34).

${ }^{50}$ I acknowledge a tension that requires investigation beyond the scope of this particular study: I uphold the worth of individuals with disabilities and differences while at 
1) The deaf shall hear and the eyes of the blind shall see (Isa 35:5; cf. 29:11-14, 18-19;

30:19-22 - healing of deaf and mute man, 7:32-37; healing of the blind man at Bethsaida, Mark 8:22; healing of blind Bartimaeus, 10:46).

2) The lame shall leap like a deer and the tongue of the dumb shall sing for joy (Isa 35:6; 29:24; 32:3-4 - healing of the paralytic, Mark 2:1-10; healing of the man with palsy, 3:1-6; healing of the deaf and dumb man; 7:32-37; healing of the boy with the mute spirit, 9:14-29).

3) The dead shall live, their corpses shall rise (Isa 26:19 ${ }^{51}$ _'raising' of the Gerasene demoniac from the tombs; raising of Jairus's daughter, 5:35-43; 'raising' of the boy with the mute spirit who appears to be dead, 9:26-27).

With the exception of death, these natural disabilities are not sources of major ritual impurity for the average Israelite; but such disabilities are sources of ceremonial defilement for the priests who represent them, and exclude someone in the Aaronic line from sanctuary service: those who are blind, lame, or otherwise physically impaired profane the sanctuary if they

the same time recognizing that 'an essential part of the restorationist eschatological view [is] that people are not meant to be deaf, blind, lame, indigent, subject to violence, and deprived of access to judicial process'. Joseph Blenkinsopp, Isaiah 1-39: A New Translation with Introduction and Commentary, AB 19 (New York: Doubleday, 2000), p. 409.

${ }^{51}$ In light of the larger context (e.g., 'the dead do not live; shades do not rise', v. 14), it is this text likely reflects some sort of belief in the survival of God's people after death based on 'the conviction that Yahveh is God of the living whose gift is life', a belief that becomes more precisely delineated in texts like Dan 12:2. See the discussion in Blenkisopp, Isaiah 1-39, pp. 370-317. 
draw near to it (Lev 21:18-24, esp. v. 23; cf. 21:11; Num 19:11-13). ${ }^{52}$ The repetition of the same list of disabilities disqualifies animals from use as sacrifices (Lev 22:17-25), suggesting that everything that approaches the altar must be blemish-free as a symbol of God's holiness and perfection.

Yet in the last days, Isaiah promises the restoration of all blemished bodies, indeed, of all blemished creation when God comes to reign among his people (Isa 29:17-24; 35:10). ${ }^{53}$ The prophet employs blindness and deafness both metaphorically ${ }^{54}$ and literally — with other natural disabilities, injustice, violence, and a spoiled ecology — to convey a problem with the current created order that must be rectified for God to reign. God will set this problem right when he comes to redeem his people, individually and corporately, so that they may live in his presence. ${ }^{55}$ Isaiah promises the purification of God's people through the healing of the human body, redemption from sin, and the renewal of the earth, so that all of creation will be transformed on the day of salvation as a mark of God's presence and reign (Isa 35:3-5). As a result, God's people will approach Zion on a holy highway upon which nothing unclean may travel (Isa 35:8).

${ }^{52}$ In fact, Qumran sectarians extend this principle to the entire camp because they view the Yahad as a priestly community of the last days that must maintain strict purity in preparation for a holy war against the forces of evil (1QS 4:6; 1Q34 3 ii 6 bis; 4Q174 1.6; CD 6:15-18).

${ }^{53}$ Blenkinsop, Isaiah 1-39, p. 409.

${ }^{54}$ Isa $6: 9-10 ; 28: 11-13 ; 29: 9-12 ; 30: 9 ; 42: 7,16,18-20 ; 43: 8 ; 56: 10 ; 59: 10$.

${ }^{55}$ See the discussion in Blenkinsopp, Isaiah 1-39, pp. 409-10, 456-57. When God restores Judah to rule, he will set right all that is awry in the created order, not only afflictions of the body, but also violence, injustice, ecological disturbances. See esp. Isa 35:5-7; 29:18; $30: 21 ; 32: 3-4 ; 33: 23$. 
While the Torah describes effective yet impermanent purification that enables people to dwell with their God imperfectly now, Isaiah describes permanent purification that enables people to dwell with their God perfectly forever. Mark consequently presents Jesus as the one who has come to inaugurate God's eschatological reign and serve as the agent who begins to transform the crippled creation and its bodies in anticipation of God's unfiltered presence among his people. The evangelist locates the announcement of 'the beginning of the good news of Jesus Christ' (Mark 1:1) regarding the establishment of God's reign at the culmination of Israel's history by interpreting it ${ }^{56}$ with a mixed citation attributed to Isaiah (Isa 40:3, Mal 3:1//Exod 23:20 in 1:2-3), ${ }^{57}$ suggesting that these texts play an important role in Mark's overall literary and theological aims. ${ }^{58}$ It is plausible that an informed audience might infer that Jesus's announcement of the nearness of God's reign (1:14-15) and his subsequent acts of healing and exorcisms signal the rectification of impurity that the Torah anticipates and the prophet promises.

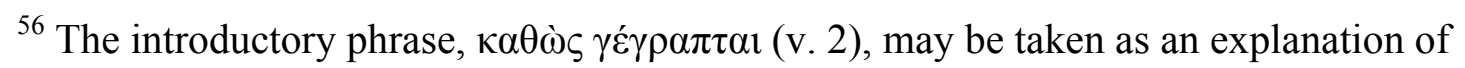
v. 1. Rikki E. Watts, Isaiah's New Exodus in Mark, WUNT 2/88 (Tübingen: Mohr Siebeck, 1997); repr., Biblical Studies Library (Grand Rapids: Baker Academic, 2000), 56; Joel Marcus, The Way of the Lord: Christological Exegesis of the Old Testament in the Gospel of Mark (Louisville, Ky.: Westminster John Knox, 1992), p. 20.

${ }^{57}$ Mal 3:1 may exhibit a rewriting of Exod 23:20 in order to draw attention to Israel's faithlessness to the covenant. Beth Glazier-McDonald, Malachi: The Divine Messenger (SBLDS 98; Atlanta: Scholars Press, 1987), pp. 130-31.

${ }^{58}$ Scholars who argue that the opening citation is programmatic for the rest of the Gospel include Marcus, Way of the Lord, pp. 12-22; Watts, Isaiah's New Exodus, pp. 53-90. See also Lane, Mark, 45-47; Schweizer, Mark, pp. 29-30; and Anderson, 'Old Testament in Mark's Gospel', pp. 280-306. 


\section{JESUs's HEALINGS AND EXORCISMS IN THE MARKAN CONTEXT}

The plausibility of this inference is strengthened by Mark's use of the language and image of purity to portray Jesus's healings and exorcisms.

First, Mark introduces Jesus's public ministry as a contest between holiness and impurity at the outset of the narrative. In proximity to the prologue, Jesus's initial, public, authoritative act at the Capernaum synagogue is striking in its juxtaposition of the man

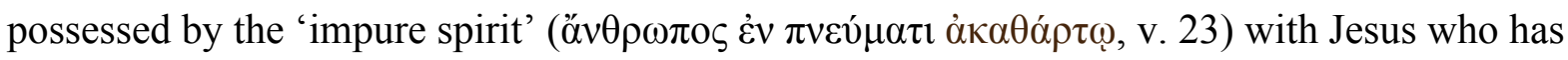

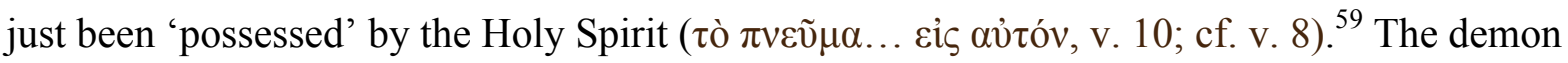
asks, 'Have you come $(\tilde{\hat{\eta}} \lambda \theta \varepsilon \varsigma)$ to destroy us $(\dot{\eta} \mu \tilde{\tau} v)$ ? I know who you are - the Holy one of God.' (v. 24). The use of the plural $\dot{\eta} \mu \mathrm{i} v$ juxtaposed with the singular verbs in 1:23-26 indicates that this spirit is a spokesperson for the demonic realm, asking if Jesus, the Holy One, has come to destroy the whole lot. ${ }^{60}$ Jesus' rebuke, 'be silent, and come out of him!' (v. 25) suggests a positive answer to the question. Later, when a search party finds Jesus after he has gone off to pray, he responds, 'Let us go on to the next towns, so that I may preach there also, for that is why I came out ( $\dot{\varepsilon} \xi \tilde{\eta} \lambda \theta$ ov, v. 38$){ }^{, 61}$ Jesus consequently travels throughout Galilee preaching and casting out impure spirits as the enactment of his mission.

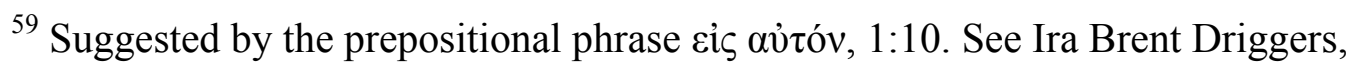
Following God Through Mark: Theological Tension in the Second Gospel (Louisville: Westminster John Knox, 2007), pp. 11-12.

${ }^{60}$ See also Clinton Wahlen, Jesus and the Impurity of Spirits in the Synoptic Gospels (Tübingen: Mohr Siebeck, 2004), pp. 91.

${ }^{61}$ T. A. Burkill also connects the demon's question, $\tilde{\eta} \lambda \theta \varepsilon \varsigma$ ('have you come?') in v. 24, with Jesus' statement, $\grave{\varepsilon} \xi \tilde{\eta} \lambda \theta$ ov ('I came out') in v. 38, and emphasizes Jesus' divine purpose to come into the world to preach the gospel, pointing ahead to 2:17. T. Alec Burkill, 
Second, Jesus' exorcisms are cast in terms of purity. The phrase 'impure spirits'

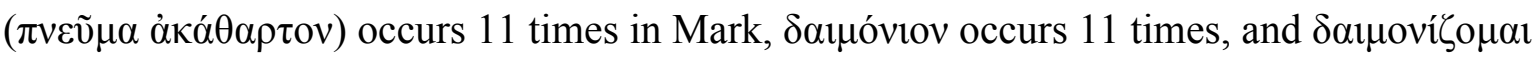
occurs 4 times. At first glance, then, the frequency of $\pi v \varepsilon \tilde{v} \mu \alpha \dot{\alpha} \kappa \alpha \dot{\theta} \theta \alpha \rho \tau \nu$ seems insignificant. But the phrase appears in Mark more than in the other synoptics combined and its usage is striking. While Mark uses 'demons' in summary statements and in reports of what others say $(1: 34,39 ; 6: 13)$, in the commissioning of the Twelve (3:14), and three times in the story of the Syro-Phoenician woman $(7: 26,29,30)$, he uses 'impure spirit' in accounts of specific exorcisms (including at opening of Jesus's encounter with the Syro-Phoenician woman), and in the Beelzebul discourse. ${ }^{62}$ This usage suggests that Mark is interested in featuring demons as impure spirits, that is, as spirits that defile.

Third, Clinton Wahlen observes that exorcisms of impure spirits introduce three clusters of healing stories, respectively; and that the cleansing of the leper introduces the cluster of stories in $2: 1-3: 6 .^{63}$

\section{1:21-28 Exorcism in Capernaum synagogue}

1:29-31 Healing of Peter's mother-in-law (fever)

Mysterious Revelation: An Examination of the Philosophy of St. Mark's Gospel (Ithaca, N.Y.: Cornell University Press, 1963), p. 37.

${ }^{62}$ Wahlen argues that the phrase 'impure spirit' derives from the tradition rather than from Mark's hand, and that Mark prefers the term 'demon' found in the summary statements alongside commands to secrecy. Wahlen maintains that Mark nevertheless gives a prominent role to impure spirits in order to communicate 'bilingually', that is, to use the same terminology about purity for both Jews and Gentiles. Clinton Wahlen, Jesus and the Impurity of Spirits, 106-107. I am arguing, contra Wahlen, that Mark not only inherits 'impure spirits', but also prefers and multiplies the phrase over and against the other Gospels.

${ }^{63}$ Clinton Wahlen, Jesus and the Impurity of Spirits, p. 83. 
1:40-45, Healing of the leper

2:1-12, Paralysis (withered body)

3:1-6, Paralysis (withered hand)

5:1-20 Exorcism of Gerasene demoniac

5:22-24, 35-34, Raising of Jairus' daughter

5:24-34, Healing of woman with issue of blood

7:24-30, Exorcism of impure spirit

7:31-37, Healing of deaf and mute man

Jesus's anger ( $\left.\rho^{\rho} \rho \gamma \sigma \theta \varepsilon i \varsigma^{64}\right)$ in the account of the leper may be interpreted as a reaction against the evil spirits responsible for the disease. In that case, the second cluster is introduced with a healing cum exorcism, and the Gospel with accounts in which the conceptual worlds of demonic possession, illness, and ritual impurity overlap. Additionally, I note that a fifth cluster, framed by healings of blind men $(8: 22-52 ; 10: 46-52)$ has the exorcism of an impure spirit in the center (9:14-27). That exorcism, like the larger unit in which it fits, addresses issues about human ability to perceive Jesus' person and mission. Cumulatively, these clusters highlight a connection between exorcisms and healings throughout the Gospel and evoke a symbolic world in which impurity, evil spirits and illnesses are interconnected. That is, the language of 'impure spirits' exposes the depth of the human plight, such that the

${ }^{64}$ I read ỏ $\rho \gamma 1 \sigma \theta$ cíc with the Western witnesses (for example, D and Old Latin) rather than $\sigma \pi \lambda \alpha \gamma \chi v i \sigma \theta \varepsilon i \varsigma_{\zeta}$ ("moved with pity"), though it is more widely attested (for example, $\aleph, \mathrm{A}$, $\mathrm{B}, \mathrm{C})$. It is more natural to explain why a scribe would alter a text from ỏ $\rho \gamma \imath \sigma \theta \varepsilon i s$ to $\sigma \pi \lambda \alpha \gamma \chi \operatorname{vi\sigma } \theta \varepsilon i \varsigma$ rather than the other way around. See also C. E. B. Cranfield, The Gospel According to Mark CGTC (Cambridge: Cambridge University Press, 1966), p. 92 and Joel Marcus, Mark 1-8 AB 27 (New Haven: Yale University Press, 2000), p. 206. 
current upside-down state of affairs is explained as the time of Belial's rule. ${ }^{65}$ Disease and bodily afflictions are not only a matter of natural processes, but are also a matter of evil spirits at work. The expectation is that when the Messiah appears, he will destroy Satan and all the spirits of impurity. Thus, Mark communicates Jesus's assault on Satan's reign through his exorcisms and healings as purification, not only by means of content, but also by means of narrative arrangement.

\section{RESURRECTION OF THE BODY AND PuRIFICATION In MARK}

Thus far, I have made the case that Mark's Jesus inaugurates God's reign, initiating the purification of a damaged world, in part, through exorcisms and healings. Through these acts, Jesus attends to the human body and its mortality. Since Jesus has announced the nearness rather than the consummation of God's reign, however, his healings and exorcisms remain anticipatory of its fulfilment. Thus, I suggest that Jesus's healings and exorcisms anticipate his bodily resurrection whereby he overcomes death and experiences the purification that expresses the reality of and the ultimate inauguration of God's reign. While the earliest and most reliable ending of Mark's Gospel (16:8) ${ }^{66}$ famously does not narrate Jesus's resurrection

${ }^{65}$ 1QM 14.9; 1QS 1.11-12; 2.19; 3.21-25; CD 12.23; 15.17; 11QMelch.

${ }^{66}$ The rise of textual criticism has yielded this consensus. The manuscript tradition attests to a "shorter" ending (an inclusion between vv. 8-9) and a "longer" ending (vv. 9-20). The "shorter" ending is attested in the uncial Greek mss. of the 7th - 9th centuries $(\mathrm{L}, \Psi, 099$, 0112), the margin of the Harclean Syriac ms., the Sahidic and Boharic mss. In addition, some Ethiopic mss. include it after 16:8 and then continue with vv. 9-12. More manuscript support is extant for the "longer ending" (A C D K W X $\Delta \Pi \Psi \mathrm{f}^{13}$ ), but the oldest Greek mss. ( $\mathrm{N}$ and B) omit vv. 9-12. For a full discussion of the text critical issues, see Bruce M. Metzger and Bart D. Ehrman, The Text of the New Testament: Its Transmission, Corruption, and 
appearances, it does narrate an announcement of Jesus's corporeal disappearance and an encounter with a corpse-less tomb. As Alan Segal states, this portrayal "denies the notion that Jesus' resurrection is merely as a "spirit", no different in theory than any other death' ${ }^{67}$

The idea of resurrection is not without precedent. The book of Daniel has a clear influence on the Gospel of Mark and its cultural encyclopedia, ${ }^{68}$ and so its description of the resurrection of God's people (Dan 12:1-3) may be significant for Mark's Gospel. According to Daniel, God's people will be delivered and 'many who sleep in the dust of the earth shall awake, some to everlasting life, and some to everlasting shame and others to everlasting contempt. Those who are wise shall shine like the brightness of the sky and those who lead many to righteousness like the stars forever and ever' (Dan 12:2-3). Daniel's hope in a resurrection of both the unrighteous and the righteous 'who sleep in the dust of the earth' is not explicit, but suggestive of a bodily resurrection to receive one's 'just deserts. ${ }^{69}$

Restoration (New York: Oxford University Press, 2005), 322-27. Recently, Nicholas P. Lunn reexamined the evidence to argue that 16:9-20 is Mark's original ending in The Originial Ending of Mark: A New Case for the Authenticity of Mark 16:9-20 (Eugene, OR: Pickwick Publications, 2014). He seeks to demonstrate weaknesses in customary arguments against both external and internal evidence, but a number of methodological flaws prevent his success. See my review of his book in $R B L$, October 10, 2017.

${ }^{67}$ Alan Segal, Life After Death: A History of the Afterlife in Western Religion (New York: Doubleday, 2004), p. 451.

${ }^{68}$ For a discussion of Daniel's influence on Mark, see Adela Yarbro Collins, 'The Influence of Daniel on the New Testament', in J. J. Collins, Daniel: A Commentary on the Book of Daniel (Minneapolis: Fortress Press, 1993), pp. 97-98.

${ }^{69}$ Segal, Life After Death, p. 265. The prophets (e.g., Isa 26:19; Ezek 37) may inform Daniel's language and metaphors for resurrection. 
The story of the martyrdom of the mother and her seven sons in 2 Macc 6-7 more clearly indicates bodily resurrection at the end of the age. When faced with death, several sons affirm their hope that God will raise them to new life (e.g., 2 Macc 6:9, 11, 14). In addition, Segal draws attention to the words of their mother, who pleads with her sons to stand firm on the basis of her belief in God's power to create life: ${ }^{70}$

I do not know how you came into being in my womb. It was not I who gave you life and breath, nor I who set in order the elements within each of you. Therefore the Creator of the world, who shaped the beginning of humankind and devised the origin of all things, will in his mercy give life and breath back to you again, since you now forget yourselves for the sake of his laws. (2 Macc 7:22-23, NRSV)

In this context, we encounter the first expression of creation ex nihilo in the mother's appeal to her son: "I beg you, my child, to look at the heaven and the earth and see everything that is in them, and recognize that God did not make them out of things that existed. And in the same way the human race came into being" (2 Macc 7:28). Segal notes that the mother's point is not to generate a philosophical or doctrinal discussion, but to stress that God's creative power is so great that he can raise the dead even if he has no raw material, that is, no corpse with which to work. ${ }^{71}$ This appeal to bodily resurrection in the Maccabees, and other martyr texts like Daniel and the Gospels, impresses upon audiences that martyrs get their bodies back. Thus the promise of bodily resurrection, coupled with punishment for the wicked and reward for the righteous, assures those who die for the sake of God's commands

\footnotetext{
${ }^{70}$ Segal, Life After Death, pp. 269-72.

${ }^{71}$ Segal, Life After Death, 269-70.
} 
- or for the sake of Jesus and the gospel (see, e.g., Mark 8:34-9:1) - that God is faithful to his covenant promises and that God's people have value beyond the physical world. ${ }^{72}$

Other Second Temple texts clearly speak of bodily resurrection. For instance, $1 \mathrm{QH}^{\mathrm{a}}$ $22,33-34,37$ contrasts images of a dying body with images of a rising body; ${ }^{73}$ PseudoEzekiel (4Q385, 4Q386, 4Q388) reuses Ezekiel's dry bones vision in order to explain bodily resurrection as the reward for the pious who are dead and buried; ${ }^{74}$ and 1 Enoch 25 describes a fragrant tree that gives life to dead bones. ${ }^{75}$ In particular, the Messianic Apocalypse (4Q521) shares significant themes with Mark. The writer speaks of the appearance of the Messiah and the reward for the pious in the Lord's eternal kingdom, which consists of 'setting prisoners free, opening the eyes of the blind, raising up those who are bowed down'

${ }^{72}$ Segal, Life After Death, p. 394. By contrast, immortality of the soul may have appealed to Jewish elite situated in Greco-Roman culture, in which Platonism underscored that the consciousness could live on without the need for the body. Idem., 394, 478.

${ }^{73}$ See the analysis of this text by George J. Brooke, 'The Structure of 1QHa XII 5XIII 4 and the Meaning of Resurrection', in F. García Martínez, A. Steudel, and E. Tigchelaar, eds., 4QMMT to Resurrection: Mélanges qumraniens in hommage à Émile Puech, (Leiden; Boston: Brill, 2006).

${ }^{74}$ This reuses Ezekiel's dry bones vision and describes the joining of bone to bone and joint to joint, then the covering of arteries and skin, and finally the blast of a heavenly breath that brings bodies to life. See Mladen Popović, 'Bones, Bodies, and Resurrection in the Dead Sea Scrolls', in T. Nicklas, F. V. Reiterer, and J. Verheyden, eds., The Human Body in Death and Resurrection (Deuteronomical and Cognate Literature Yearbook 2009; Berlin: de Gruyter, 2009), p. 231.

${ }^{75}$ The righteous enter into the holy place, and the fragrance of the tree will permeate their bones to give them life. 
(4Q521 2 ii +4 , quoting Psalm 146:7-8). At that time, the Lord will 'do glorious things which have not been done' (4 ii 11)—namely, he will raise the dead. The writer speaks of bodily resurrection twice. First, the Lord 'shall heal the critically wounded, he shall revive the dead' (4Q521 $2+4$ ii 12). This warrants an announcement of 'good news' to those in trouble in the words of Isa 61:1 (4 ii 13; compare Mark 1:1, 10). Second, the Lord is 'the One who revives and [rai]ses the dead of His people' (4Q521 $7+5$ ii 6). In this text, liberation and healing lead to the climactic blessing of bodily resurrection for God's people. In Mark, something similar happens, but with a twist: liberation and healing lead (eventually) to the climactic bodily resurrection of Jesus. In what follows, I seek to demonstrate that Mark both anticipates the bodily resurrection of Jesus and ties it to that of human beings by evoking the idea of bodily resurrection in healings and exorcisms throughout the narrative.

1. Resurrection as the means for entering God's reign

Mark speaks of the reign, or kingdom of God, as something that can belong to people or that people can receive (10:14-15); but he overwhelmingly presents it as something that

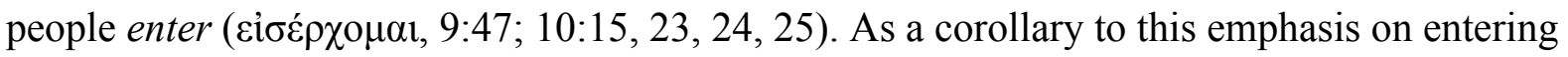
God's reign, Mark uses spatial metaphors to describe it: the reign of God is near (ク̋ $\gamma \gamma 1 \kappa \varepsilon v$, 1:15); those 'inside' have been given the secret of the reign of God while those outside (' $\xi \omega)$ receive everything in parables (4:11) the lone scribe is not far (ov̉ $\mu \alpha \kappa \rho \grave{v} v$ ) (from entering it).

One has access to the reign of God by repenting and believing the good news (1:15); receiving the 'secret' of the kingdom/reign (4:11); hearing the sown word with open ears (ch. 4); having a childlike disposition (10:14-15); and selling all one's goods, giving to the poor and following Jesus (10:1-31). But while these provide access to God's imminent reign resurrection provides access to God's powerfully implemented reign when it is consummated. Jesus predicts three times that he will suffer, die and rise, and he calls his followers to imitate him in following this pattern $(8: 31 ; 9: 31 ; 10: 32-34)$. After each prediction, however, the 
disciples expose their misunderstanding of Jesus' mission and reject Jesus' call to imitate his pathway into the kingdom. They repeatedly bicker over status in the kind of kingdom they imagine Jesus will establish, and obstruct those they deem to lack status (e.g., 9:38-41; 10:1316). Jesus responds by teaching what it means to follow him $(8: 32-37 ; 9: 32-37 ; 10: 35-45)$. Finally, Jesus gives his own attitudes and actions as the quintessential example of his teaching: 'the Son of Man came not to be served, but to serve and to give his life as a ransom for many' $(10: 45)$.

After Jesus' first passion prediction, he tells his followers that 'there are some standing here who will not taste death until they see that the reign of God has come with

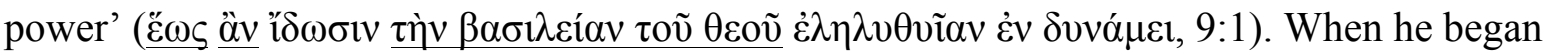

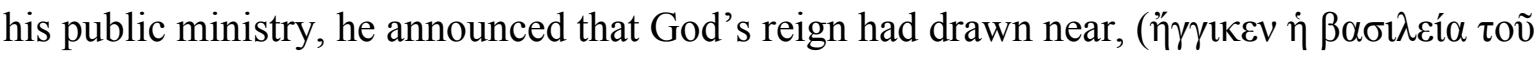
$\theta \varepsilon o \tilde{v}, 1: 15)$, but now he anticipates that it will come with power. This anticipation with the narrative placement of 9:1 suggests that the transfiguration functions as a proleptic view of the power of God's reign, anticipating both the resurrection and Parousia. ${ }^{76}$

At the Passover meal, Jesus looks towards his death by likening the broken bread to his body and the wine to his shed blood. Yet he also looks towards his resurrection by saying, 'I will never again drink of the fruit of the vine until that day when (

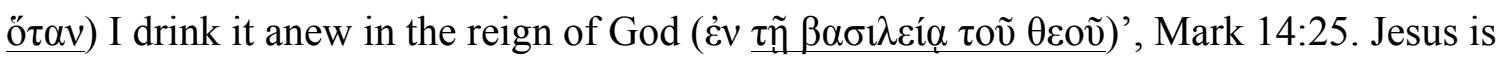
saying that he will drink anew, that is, again or at a new time. The adverb 'seems to imply

${ }^{76}$ The powerful coming of the kingdom of God in 9:1 is likely a restatement of the appearance of the Son of Man in 8:38, using different language. See also Norman Perrin, Rediscovering the Teaching of Jesus (London: SCM Press, 1967), 199. C. E. B. Cranfield, The Gospel According to Mark, Cambridge Greek Testament Commentary; C. F. D. Moule, ed. (Cambridge: CUP, 1966), p. 288. 
temporal interruption followed by resumption. ${ }^{77}$ Jesus' eating and drinking will be interrupted by his suffering and death, but will resume at some point after his resurrection. ${ }^{78}$ The prepositional phrase signifies that Jesus will have entered the kingdom of God to enjoy God's unfiltered presence, I suggest, by means of his resurrection.

When Jesus submits to death on the cross, he encounters the painful result of mortality. Moreover, he cries out in a loud voice in such a way that recalls the cries of those from whom he had cast impure spirits (cf. 1.26; 5.7), suggesting a final confrontation with the impure spirits in his own body. He experiences the judgment of God in the darkness that overcomes the land and is accursed as he cries out that God has forsaken him. ${ }^{79}$ Yet, Jesus has said that he will enter God's reign to share in the eschatological banquet. An informed audience may infer, therefore, that the raising of Jesus's body not only vindicates him, but also purifies him by transforming the mortality inimical to God's rule in order to bring an accursed Jesus into the new state of resurrection life that corresponds to the immortal life characteristic of a holy God. ${ }^{80}$

${ }^{77}$ Joel Marcus, Mark 8-16: A New Translation with Introduction and Commentary (AYB 27A (New Haven: Yale University Press), p. 959. Bruce Chilton argues that the syntax of this verse is not rigidly temporal, but that Jesus looks ahead to sharing the eschatological feast with his purified followers. Bruce Chilton, Pure Kingdom: Jesus' Vision of God (Grand Rapids: Eerdmans, 1996), pp. 86, 88.

${ }^{78}$ Cranfield states that the verse could refer to the messianic feast or (his preference) to 'the period between the Resurrection and Ascension'. Cranfield, Mark, p. 428.

${ }^{79}$ See the discussion of the real sense in which Jesus was forsaken in Marcus, Mark 816, pp. 1061-64.

${ }^{80}$ David Moffitt surveys Second Temple literature and finds that human bodies in their mortal condition could not ascend to the heavens to enter God's presence until they are 


\section{Resurrection-type healings and exorcisms in Mark}

In looking back at Jesus's ministry from the perspective of the resurrection set forth above, it becomes clear that Mark casts Jesus's healings and exorcisms as evocative of resurrection from the dead, such that on a re-reading or rehearing of the Gospel they may be seen as resurrection-type stories, which suggests 1) that they both echo and foreshadow Jesus's own resurrection ${ }^{81}$ and 2) that Jesus's resurrection has a corresponding function to that of his followers in the new age: resurrection purifies the body, transforming the mortality and death that are inimical to God's presence, character, and rule.

I begin this discussion by recalling Joanna Dewey's observation that Mark 2:1-3:6 has a chiastic structure with literary and theological implications: A, B, C, B', A' (Mark 2:1-12, $13-17,18-22,23-28,3: 1-6) .{ }^{82}$ She notes that the C story is the first allusion to the crucifixion

somehow purified or glorified. David M. Moffit, Atonement and the Logic of Resurrection in the Epistle to the Hebrews. NovTSup 141 (Leiden: Brill, 2013), pp. 145-59. Also, Bruce Chilton shows that in the OT, purity is necessary for compatibility with God's presence or kingdom. This, he argues, forms the basis of Jesus's principles of table fellowship. Purity is thus recoverable and the basis upon which God gathers his people. Chilton, Pure Kingdom, pp. $38-40,80,90$.

${ }^{81}$ Elizabeth Struthers Malbon discusses the effect of echoes and foreshadowings in the reading and/or hearing process of Mark. These appear in the form of suggestive or allusive phrases or images, repeated words, and recurring plot movements. Elizabeth Struthers Malbon, 'Echoes and Foreshadowings in Mark 4-8: Reading and Rereading', JBL 112 (1993), p. 211.

${ }^{82}$ Joanna Dewey, 'The Literary Structure of the Controversy Stories in Mark 2:1-3:6', JBL 92 (1973), pp. 394-401. 
and fits within two outside stories, A and A', that are concerned with 'resurrection' type healings. The 'raising' of the paralyzed man from his bed portrays a metaphorical movement from death to life. The healing of the man with a withered hand-like that of a corpse - also signifies movement from the sphere of death to life. This portrayal recalls the world of the Jewish scriptures and Second Temple Judaism, in which impurities are associated with death and mortality. Mark introduces the cycle with the healing of a leper, a man in a liminal place between life and death (1:40-45). While Dewey concludes that the cycle of stories in 2:1-3:6 is consistent with Mark's theology of the cross, ${ }^{83}$ I suggest that this cycle also foreshadows the necessity of seeing the cross in light of the resurrection.

The structure and content of 4:35-5:43 confirm Mark's emphasis on resurrection. When Jesus calms a storm his disciples ask an unanswered question: 'Who is this, that even the wind and the sea obey him?' (4:41). A subsequent series of resurrection-type stories suggests an answer (ch. 5): the exorcism of the Gerasene demoniac, the raising of Jairus' daughter, and the healing of the 'daughter' with the issue of blood. ${ }^{84}$ As the audience experiences the text linearly they may also reflect retrospectively upon the disciples' question from 4:41, 'Who is this?' - Jesus is the one through whom God reveals power to bring life from death.

Additionally, the narrative exhibits the repetition of 'resurrection' words, themes, and ideas that accumulate to develop a matrix of meaning. For example, when Peter's mother-in-

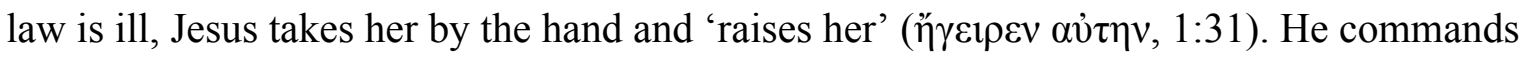
the paralytic who lays in the stance of a dead man to rise (' $\left.\varepsilon^{\prime} \gamma \varepsilon ı \varepsilon\right)$, take up his mat and walk, and consequently, he got up (literally, he was raised, $\eta \gamma^{\varepsilon} \rho \theta \eta, 2: 11$ ). When Jesus comes a little too late to heal Jairus' daughter, he takes the dead girl by the hand and commands her to

\footnotetext{
${ }^{83}$ Joanna Dewey, 'Literary Structure', p. 400.

${ }^{84}$ See my discussion of these passages above.
} 


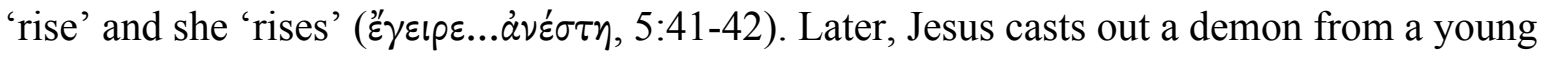
boy, and when it looks as if he is dead, Jesus takes him by the hand and lifts him up and he

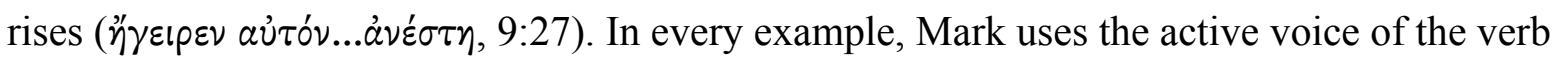
દ̇ $\gamma \varepsilon i p \omega$ to expresses Jesus's action. In addition to this, the last two examples (5:41-42; 9:27)

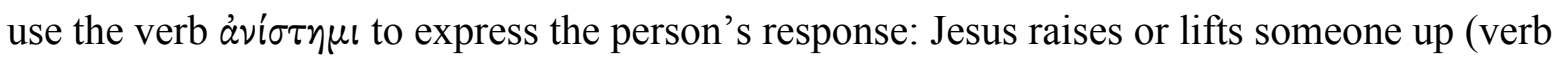

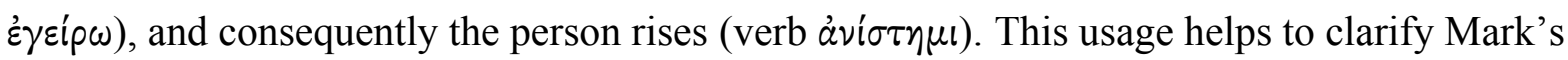
application of the same language to Jesus. In the passion predictions, Jesus teaches that the

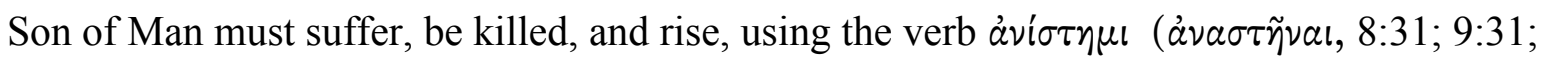
10:34; cf. 9:9-10; 12:25). Later, the young man at the tomb uses the passive form of the verb

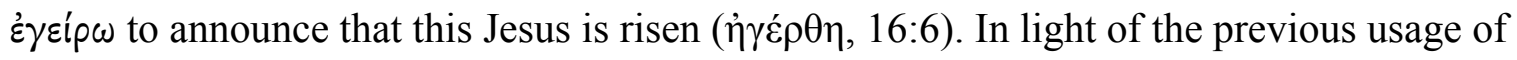
this verb, the passive voice indicates that God is now the actor: he has raised or lifted up Jesus, and consequently Jesus is risen (implied verb áví $\sigma \tau \eta \mu \iota) .{ }^{85}$ Mark has built a matrix of meaning around this concept of 'being risen,' so that upon reaching that climactic announcement in 16:6, the audience may understand from the whole narrative that God has raised Jesus to prevail over the dark power that holds human beings captive. Thus, in the process of reading or hearing the text (and re-reading or re-hearing), the audience may both make sense of Jesus's death and empty tomb, and, retroactively, the healings and exorcisms. This process, I argue, conveys a homologous relationship between the experience of Jesus and the characters and, by extension, the audience. ${ }^{86}$

${ }^{85}$ Compare Mark $6: 14,16 ; 12: 26 ; 14: 28$, which use the passive form of $\dot{\varepsilon} \gamma \varepsilon i ́ p \omega$ to convey that God raises the dead.

${ }^{86}$ Malbon argues that repetition throughout Mark creates a homologous or corresponding relationship between the characters and the readers/hearers such that everyone must hear again before they perceive. All readers and hearers become re-readers and re- 
I pull together these observations by taking a look at the exorcism in Mark 9:14-29, which recalls themes and images from earlier in the narrative. In fact, this episode is more than an exorcism, because in it Jesus encounters an impure spirit, an illness, and a 'corpse.' This episode is significant, not only because it joins these elements, but also because through it Mark explains what he means by 'resurrection'.

On the way down the mountain of transfiguration (9:2-8), Jesus tells the disciples who had accompanied him not to tell anyone what they had seen until after the Son of Man rises from the dead (9:9). The disciples ask each another what this 'rising from the dead' might mean (v. 10). The next episode answers their question. They walk into a controversy between some scribes and the rest of the disciples over the inability to cast an impure spirit out of a boy. When Jesus intervenes to cast out the spirit, the child looks so much like a corpse that most of the people in the crowd say, 'he is dead.' For a moment, it seems as if Jesus' power has failed. But Jesus takes the boy by the hand to lift him up and he rises ( $\eta$ $\gamma \varepsilon ı \rho \varepsilon \nu$

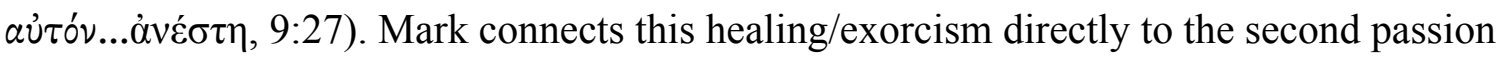
prediction (9:30-32), inviting the audience to consider one episode in light of the other. Jesus's suffering and death will make it appear that those very forces he has overcome repeatedly during his ministry have now hopelessly overpowered him. Just as the boy appeared to be dead by the work of the impure spirit, the Son of Man will appear to be defeated and destroyed when he is crucified (9:31). Just as the lifeless boy rises from 'death,' Jesus has predicted that the Son of Man, after he is killed, will rise after three days. This narrative connection suggests that the meaning of resurrection is found in the rectification of the defiling and degenerating power of illness and disability, impure spirits, and death itself.

hearers who return to the narrative for understanding. Malbon, 'Echoes and Foreshadowings', pp. 229-30. 


\section{CONCLUSION}

'Resurrection' is only absent from Mark's Gospel for those whose sole criterion is the presence of resurrection appearances at the end of the Gospel. ${ }^{87}$ Against such a view, I have demonstrated that Mark's Gospel is shot through with it. The trajectory of Mark's story is towards the climax of the empty tomb, which becomes the lens through which the healings and exorcisms may be interpreted and understood, and vice versa. Cumulatively, Jesus' healings and exorcisms are resurrection-type stories that signify the move from 'death' or mortality to the life of God's reign. The degeneration of the body is displaced by wholeness and death is displaced by life. This is the good news of the reign of God, which takes the whole narrative to communicate. The repetition of bodily healings and exorcisms (evoking the rectification of impurity) that culminate in Jesus's own resurrection from the dead (signalling the embodiment of purity) demonstrates that entering the consummated reign of God entails not only responding to the call for repentance from $\sin (1: 14-15)$, but also having one's body raised. The healing of the paralytic (Mark 2:9-12) illustrates this quite literally: Jesus not only forgives the man, but also 'raises' him.

Over a century ago, Martin Kähler famously called the Gospels 'passion narratives with extended introductions'. Scholars have applied this description particularly to the Gospel of Mark, reflecting a long-running consensus that Mark's soteriological—and overall theological—stance may be summed up as a 'theology of the cross'. As a result, the first twothirds of Mark become an introduction to the Passion narrative and Mark 16, an epilogue. The consequences for understanding Markan soteriology is twofold: 1) Jesus' healings and exorcisms tend to be marginalized, even though they occupy a substantial part of Jesus'

${ }^{87}$ For example, Nicholas P Lunn recently argues that Mark has no account of Jesus's resurrection because of the absence of a resurrection appearance in the extant manuscripts. Lunn, The Originial Ending of Mark. 
mission to inaugurate the reign of God; 2) Jesus's resurrection tends to be marginalized, even though Mark explicitly links Jesus' death with resurrection in the passion predictions; 3) Human bodies tend to be marginalized in favor of a moral/ethical and internal transformation. The implication of my study is that bodies matter: healings from disease and disability, exorcisms of impure spirits, and being raised from the dead reflect Mark's thoroughgoing concern with the purification of the body at the turn of the ages. Thus, Mark presents not only a theology of the cross, but also a theology of resurrection as the purification of God's people. 